\title{
MATH TALK STRATEGI MENINGKATKAN KEMAMPUAN BERPIKIR KRITIS DAN KEMAMPUAN KOMUNIKASI DI KELAS
}

\author{
NAILUL AUTHARY \\ ${ }^{1}$ Universitas Muhammadiyah Aceh, Jl. Muhammadiyah No.91, Kota Banda Aceh, Aceh \\ nailulautharympd@gmail.com
}

\begin{abstract}
Abstrak
Kemampuan berpikir kritis dan kemampuan komunikasi menjadi dua kemampuan penting dan mendasar untuk dimiliki peserta didik. Kemampuan ini kemudian dibutuhkan untuk mendapatkan pekerjaan setelah peserta didik selesai menempuh pendidikan formal. Sadar akan kebutuhan ini, penerapan strategi math talk pada pembelajaran matematika diharapkan dapat meningkatkan kemampuan berpikir kritis dan kemampuan komunikasi. Artikel ini dikaji dengan menggunakan data kualitatif dengan menggunakan metode eksplorasi. Melalui metode eksplorasi dapat mengkaji secara mendalam mengenai penggunaan strategi math talk dalam mengembangkan kemampuan komunikasi dan kemampuan berpikir kritis. Strategi math talk pada pembelajaran matematika di kelas dimulai dengan membuat kelompok atau komunitas belajar. Penerapan strategi ini secara bersamaan mengembangkan kemampuan berpikir kritis dan komunikasi.
\end{abstract}

Kata Kunci : math talk, berpikir kritis, kemampuan komunikasi

\begin{abstract}
The ability to think critically and communicate the ability to be two important and fundamental skills for the learners. This ability is then needed to get a job after the learner has finished his formal education. Aware of this need, the application of math talk strategy in mathematics learning is expected to improve the ability of critical thinking and communication skills. This article is reviewed using qualitative data using exploratory methods. Through exploratory methods can examine in depth the use of math talk strategy in developing communication skills and critical thinking skills. The math talk strategy on learning mathematics in the classroom begins with creating a class or community learning. The application of this strategy simultaneously develops critical thinking and communication skills.
\end{abstract}

Keywords: math talk, critical thinking, communication skill

\section{Pendahuluan}

Kriteria menarik yang dikutip dari http://philosophy.hku.hk/think/critical/ct.php mengenai 10 kemampuan teratas yang diperlukan pada tahun 2020 diantaranya yaitu berpikir kritis dan kemampuan berkomunikasi. Keseluruhan kriteria tersebut adalah: 10 Top Skills in 2020 there are: Complex problem solving, critical thinking, creativity, people management, coordinating with other, emotional intelligent, judgement and Decision Making, service orientation, 
negotiation and cognitive flexibility (Joe Lau \& Jonathan Chan, 2017). Artinya, 10 keahlian teratas pada tahun 2020 diantaranya: pemecahan masalah kompleks, berpikir kritis, kreativitas, pengelolaan penduduk, koordinasi antar sesama, kecerdasan emosional, pengambilan keputusan, pelayanan, negosiasi, dan kognitif yang fleksibel. Dari 10 hal di atas terlihat bahwa berpikir kritis menduduki tempat penting dalam kemampuan yang diperlukan dimasa yang akan datang.

Selain berpikir kritis, melalui 10 kriteria yang tersebut di atas, terdapat kemampuan komunikasi yang sangat dibutuhkan yaitu dalam kemampuan berkoordinasi antar sesama, pengelolaan penduduk, dan kemampuan bernegosiasi. Ketiga kemampuan ini dapat dikategorikan kedalam kemampuan berkomunikasi. Kemampuan komunikasi juga sangat berpengaruh pada keberhasilan pembelajaran di kelas. Kemampuan berpikir kritis dan kemampuan komunikasi merupakan dua kemampuan yang dapat dieksplorasi di kelas. Salah satunya melalui pembelajaran matematika.

Pengembangan pembelajaran matematika juga bertujuan menumbuhkembangkan kemampuan berpikir kritis dan komunikasi. Berdasarkan National Council of Teaching Mathematics (2000) tujuan pembelajaran matematika di sekolah adalah: (1) komunikasi matematis; (2) penalaran matematis; (3) pemecahan masalah; (4) koneksi matematis; dan (5) representasi matematis. Lima tujuan pembelajaran ini sangat erat kaitannya dengan berpikir kritis dan kemampuan komunikasi.

Strategi menarik yang dapat digunakan adalah math talk. Telah banyak penelitian dilakukan mengenai math talk. Tidak hanya sekedar meneliti, math talk telah dikembangkan menjadi komunitas belajar yang diterapkan selama pembelajaran matematika berlangsung di kelas. Math talk permits teachers to assess students understanding on going basis. It encourages students to develop their languange skill. (2017) Artinya math talk memperkenankan guru untuk mengetahui pemahaman siswa secara berkelanjutan. Ini dapat mendorong peserta didik membangun kemampuan komunikasi.

Salah satu kelompok peneliti yang menulis mengenai math talk adalah HufferdAckles, Fuson, and Sherin (2004) menyatakan bahwa " the key components within a MathTalk Learning Community are: questioning, explaining mathematical thinking, source of mathematical ideas, and responsibility for learning. Artinya komponen kunci dalam suatu komunitas math talk adalah bertanya, menjelaskan pemikiran matematika, sumber ide-ide matematika dan bertanggung jawab terhadap pembelajaran. Dari kutipan tersebut menggambarkan komponen-komponen penting math talk yang membangun kemampuan berpikir dan komunikasi. Kelompok ini mengeksplorasi mengenai komunitas math talk yang 
diterapkan di kelas. Selain mengembangkan kemampuan berpikir matematika, kelompok ini peneliti ini menemukan bahwa kemampuan bertanya dan tanggungjawab dalam belajar juga muncul selama proses pembelajaran dengan menerapkan math talk.

Pada sisi yang berbeda NCTM (1991) menyebutkan math talk is the way of representing, thinking, talking and agreeing and disagreeing that teacher and student use to engange in task. Artinya math talk merupakan cara merepresentasikan, berpikir, mengungkapkan, setuju dan tidak setuju dimana guru dan siswa menggunakannya pada tugas.definisi dari NCTM ini semakin menegaskan bahwa math talk mengembangkan kemampuan berpikir. Definisi ini ditambah dengan kemampuan pengambilan keputusan dalam menyetujui atau tidak menyetujui suatu pendapat.

Tujuan dari tulisan ini adalah mengeksplorasi mengenai kemampuan berpikir kritis dan kemampuan komunikasi di kelas melalui math talk. Hasil dari eksplorasi ini diharapkan menghasilkan cakupan membangun kemampuan berpikir kritis dan diskusi yang bermana selama pembelajaran matematika di kelas berlangsung.

Manfaat dari tulisan ini adalah menjadikan kajian mengenai math talk yang efektif. pembelajaran matematika yang sukses sangat didukung oleh komunikasi yang baik di kelas baik antara guru dan siswa maupun antara siswa dan siswa sendiri. Sangat diharapkan terdapat komunikasi yang efektif melalui bahasa matematika. Bahasa tersebut biasanaya digunakan ketika memecahkan masalah matematika. Masalah matematika erat kaitannya dengan berpikir kritis.

\section{Metode}

Artikel ini dikaji dengan menggunakan data kualitatif dengan menggunakan metode eksplorasi. Penggunaan metode ini diharapkan mendapatkan kajian teori mengenai math talk selama pembelajaran matematika. Selain itu, metode eksplorasi dapat mengkaji secara mendalam mengenai penggunaan strategi math talk dalam mengembangkan kemampuan komunikasi dan kemampuan berpikir kritis. Berikut beberapa pertanyaan yang akan dibahas dalam artikel ini:

1. Bagaimana penerapan strategi math talk pada pembelajaran matematika di kelas?

2. Bagaimana strategi math talk bersinergi dengan kemampuan berpikir kritis dan kemampuan komunikasi?

3. Bagaimana strategi math talk dapat meningkatkan kemampuan berpikir kritis dan kemampuan komunikasi? 


\section{Pembahasan}

\section{Math Talk dan Matematika}

Pembelajaran matematika di kelas dituntut untuk mencapai tujuan pendidikan. Untuk mencapai tujuan pendidikan tersebut, salah satu strategi yang dapat digunakan oleh guru adalah math talk. Menurut NCTM (1991) menyebutkan math talk is the way of representing, thinking, talking and agreeing and disagreeing that teacher and student use to engange in task. Artinya math talk merupakan cara merepresentasikan, berpikir, mengungkapkan, setuju dan tidak setuju dimana guru dan peserta didik menggunakannya pada tugas.

Secara garis besar, math talk merupakan strategi yang digunakan oleh guru untuk meningkatkan kemampuan berpikir peserta didik melalui bertanya dan membuat pernyataan. Math talk dapat diterapkan secara berpasangan maupun berkelompok. Hal ini akan memudahkan siswa berinterksi satu sama lain untuk saling berbagi ide matematika.

Ide matematika yang abstrak dapat dikembangkan melalui pertanyaan. Selain itu, dengan menerapkan math talk pada pembelajaran, sekaligus mengeksplorasi kemampuan berpikir melalui membuat statement atau pernyataan. Berikut beberapa contoh penerapan math talk:

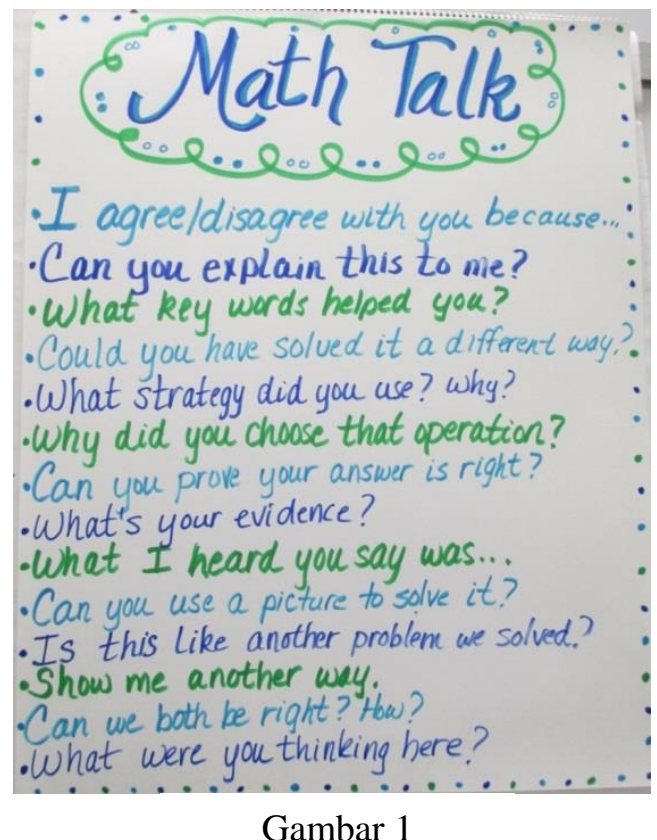

Beberapa pernyataan yang digunakan dalam math talk sesuai pada gambar 1 adalah sebagai berikut:

a. Saya setuju/tidak setuju dengan anda karena .....

b. Dapatkah anda menjelaskan hal ini kepada saya? 
c. Kata kunci apa yang telah membantu anda?

d. Apakah anda apat menyelesaikan ini dengan cara yang berbeda?

e. Strategi apa yang telah anda gunakan? Mengapa?

f. Mengapa anda memilih operasi tersebut?

g. Dapatkah anda membuktikan bahwa jawaban anda benar?

h. Apa bukti yang anda punya?

i. Apatkah anda menggunakan gambar untuk memecahkan ini?

j. Apakah ini seperti masalah lain yang kita pecahkan?

k. Tunjukkan saya cara yang lain.

1. Dapatkah kedua kita benar? Bagaimana?

m. Apa yang telah kamu pikirkan disini?

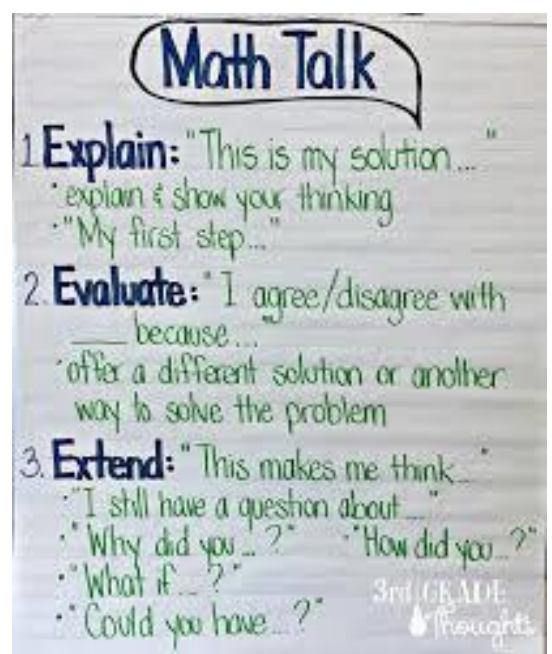

Gambar 3

Terdapat tiga hal penting dalam math talk, yaitu penjelasan, evaluasi dan pengembangan.

Berikut penjelasan dari gambar 3:

a. Penjelasan

1. Ini adalah penyelesaian saya..

2. Jelaskan dan tunjukkan pemikiran anda?

3. Langkah pertama saya...

b. Evaluasi

1. Saya setuju/tidak setuju dengan karena

2. Tunjukkan solusi yang berbeda atau cara lain untuk memecahkan masalah tersebut c. Perluasan 
1. Hal ini membuat saya berpikir......

2. Saya tetap memiliki pertanyaan tentang......

3. Mengapa anda....?

4. Bagaimana anda......?

5. Bagaimana jika....?

6. Dapatkah anda .....?

\section{Math Talk dan Kemampuan Berpikir Kritis}

Kemampuan berpikir dikelompokkan ke dalam tiga kelompok, yaitu berpikir tingkat tinggi (high level thinking), berpikir kompleks ( complex thinking) dan berpikir kritis (critical thinking). Pada artikel ini akan dieksplorasi mengenai kemampuan berpikir kritis secara khusus berkaitan dengan math talk.

Berpikir kritis merupakan kemampuan untuk berpikir jelas dan secara rasional mengenai yang dilakukan atau yang dipercayai. Pada sisi yang berbeda, menurut Fisher (1995, dalam Ifada Novikasari), apabila seseorang sedang melakukan proses berpikir kritis berarti menjelaskan bagaimana suatu itu dipikirkan. Belajar berpikir kritis berarti belajar bertanya, kapan bertanya dan metode penalaran yang digunakan. Proses belajar seperti inilah yang diharapkan dapat dikembangkan melalui penerapan strategi math talk di kelas sehinga peserta didik memiliki kemampuan berpikir kritis.

Seseorang dikatakan mempunyai kemampuan berpikir kritis jika mampu menganalisis fakta, menggeneralisasi dan mengorganisasikan ide, mempertahankan opini, membuat perbandingan, menarik kesimpulan, menguji argumen dan menyelesaikan masalah (Chance dalam Ifada Novikasari, 1986)

Kemampuan berpikir kritis dapat ditingkatkan pada pembelajaran matematika dengan melibatkan proses mental, misalnya mengelompokkan, memutuskan, menyeleksi dan mengambil kesimpulan. Berdasarkan pemikiran di atas, maka dapat disimpulakan bahwa peningkatan kemapuan berpikir kritis dapat dilakukan dengan melibatkan siswa secara aktif, pengajuan masalah yang menantang, dan siswa mengambil kesimpulan sendiri.

Berdasarkan penjelasan di atas, penerapan math talk melalui proses c merepresentasikan, berpikir, mengungkapkan, setuju dan tidak setuju dapat meningaktkan kemampuan berpikir kritis.

\section{Math Talk dan Kemampuan Komunikasi di Kelas}


Komunikasi merupakan hal penting dalam interaksi di kelas. Komunikasi di kelas terdiri dari tiga kategori yaitu verbal, nonverbal dan tulisan. Komunikasi verbal adalah semua yang guru atau siswa ucapkan. Komunikasi nonverbal adalah bahasa tubuh yang digunakan seseorang. Sedangkan komunikasi tertulis adalah ditulis secara langsung oleh guru maupun peserta didik, baik berupa lembar jawaban ataupun tugas siswa.

Ketiga bentuk komunikasi di atas juga berlangsung selama proses pembelajaran matematika. Proses komunikasi di kelas terjadi melalui proses diskusi dan memberikan beberapa manfaat. Mathematics discussion help us learn from each other, and we get to help other learn. Artinya diskusi matematika membantu untuk belajar dari yang lain, dan kita dapat membantu yang lain belajar.

Hal yang terpenting lain dalam komunikasi adalah kemampuan mengungkapkan ide matematika. Math talk is simply way for student to have meaningful student to student conversation about math while learning to respect and understand there is more than one way to correctly approach and solve a problem (Genia Connell, 2014) Artinya math talk merupakan cara sederhana untuk memperoleh percakapan matematika bermakna antara siswa dan siswa, selain itu belajar untuk menghargai dan mengerti, terdapat lebih dari satu cara pendekatan yang benar dan memecahkan suatu masalah.

Selain itu, Math talk permits teachers to assess students understanding on going basis. It encourages students to develop their languange skill (Introduction to Math Talk, di akses Februari 2018). Artinya math talk memberikan kesempatan guru untuk menguji pemahaman peserta didik selama proses pembelajaran. Hal ini (math talk) mendorong siswa untuk membangun kemampuan bahasa mereka. Selain mendukung komunikasi antara peserta didik dan peserta didik, math talk juga membangun kemampuan berbahasa.

\section{Sinergi Antara Math Talk, Kemampuan berpikir Kritis dan Kemampuan Komunikasi}

Karakteristik math talk yang mengembangkan kemampuan peserta didik dapat diperhatikan melalui keterkaitannya dengan kemampuan berpikir kritis dan kemampuan komunikasi. Dalam hal ini, math talk tidak hanya berhubungan antara kemampuan berpikir kritis saja atau math talk berhubungan dengan kemampuan komunikasi saja. Akan tetapi ada hal menarik yang dapat di perhatikan adalah adanya sinergi antara strategi math talk dengan kedua kemampuan tersebut. 


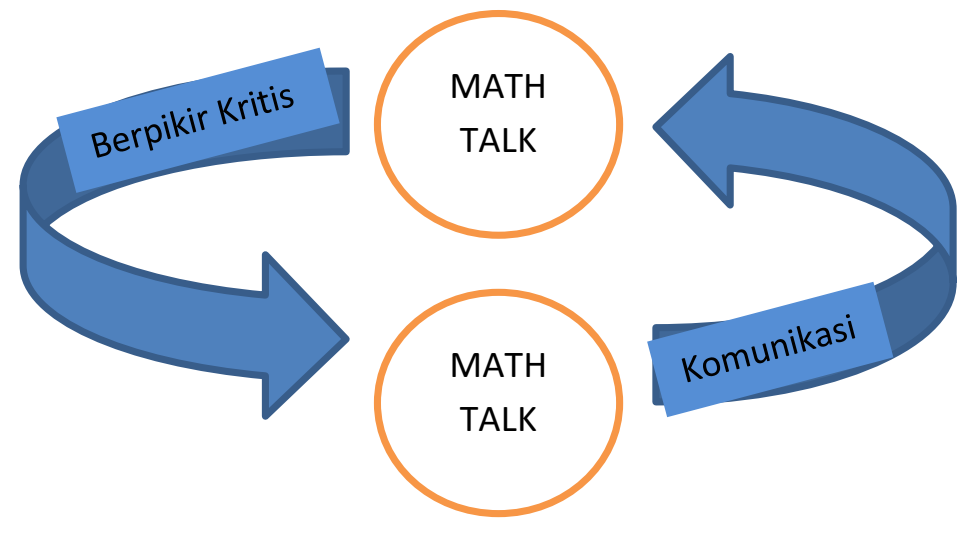

Diagram 1

Berikut disajikan karakteristik math talk dan sinerginya dengan kemapuan berpikir kritis dan kemampuan komunikasi:

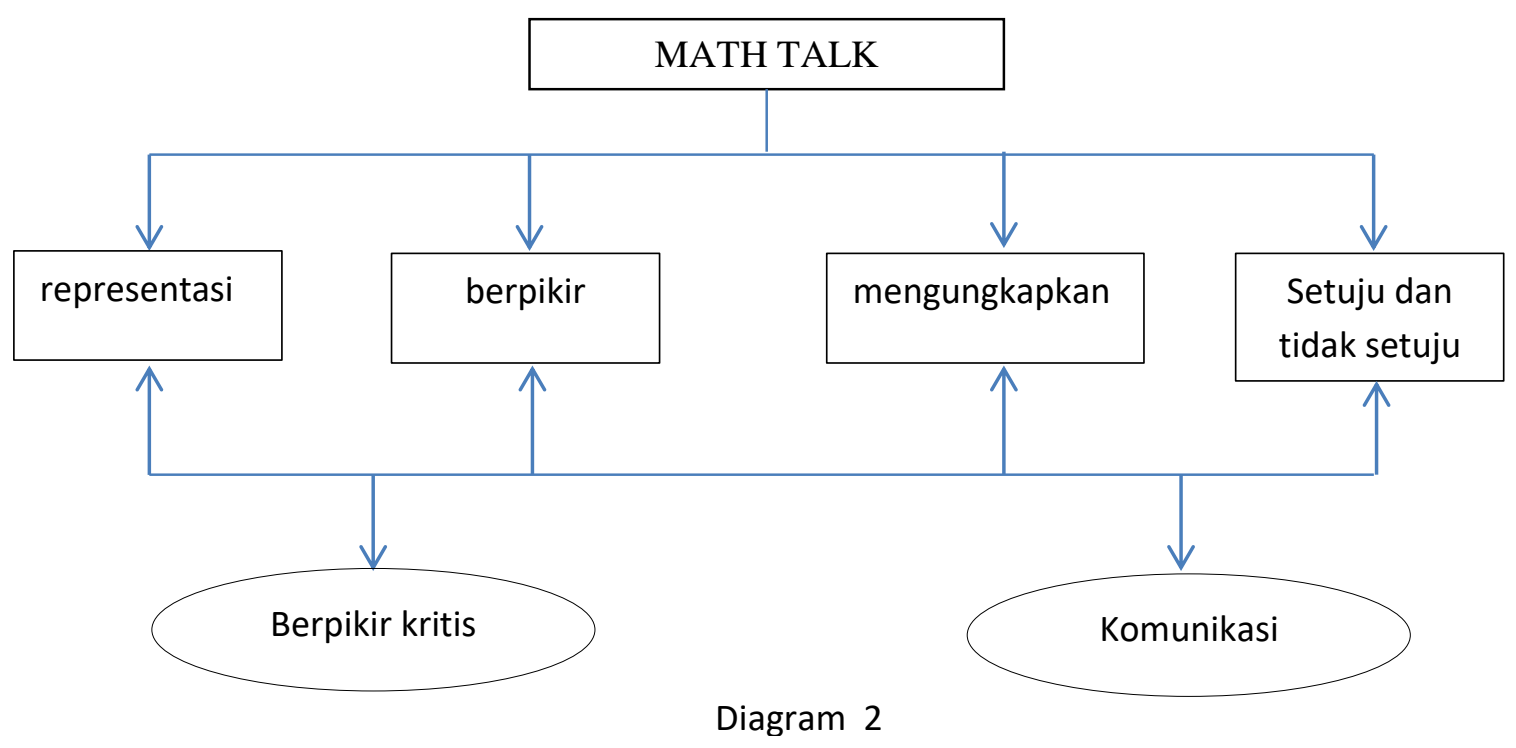

Tabel 1. Kategori dan Komponen math talk, berpikir kritis dan komunikasi

\begin{tabular}{l|l}
\hline \multicolumn{1}{c|}{ Kategori } & \multicolumn{1}{c}{ Komponen } \\
\hline Math Talk & 1. Representasi \\
& 2. Berpikir \\
& 3. Mengungkapkan \\
& 4. Setuju dan tidak setuju \\
\hline Kemampuan berpikir kritis & 1. menganalisis fakta \\
& 2. menggeneralisasi \\
& 3. Mengorganisasikan ide, \\
& 4. mempertahankan opini \\
& 5. menarik kesimpulan, \\
& 6. menguji argumen \\
& 7. menyelesaikan masalah \\
& 8. mengelompokkan \\
\hline
\end{tabular}




\begin{tabular}{l|l}
\hline & 9. menyeleksi \\
\hline Kemampuan Komunikasi & 10. mengambil kesimpulan \\
\hline & 1. percakapan matematika bermakna \\
& 2. belajar untuk menghargai \\
3. belajar mengerti, \\
4. diskusi matematika membantu untuk \\
\\
5. melajar dari peserta didik lain, \\
\\
6. belajar hubungan antara peserta didik \\
7. meningkatkan kemampuan berbahasa \\
\hline
\end{tabular}

\section{Simpulan}

Berdasarkan pembahasan dan diskusi di atas mengenai math talk serta kaitannya dengan meningkatkan kemampuan berpikir kritis dan komunikasi, kesimpulan dari artikel ini diantaranya :

1. Penerapan strategi math talk pada pembelajaran matematika di kelas dimulai dengan membuat kelompok atau komunitas belajar di kelas disaat pembelajaran matematika berlangsung. Kemudian dilanjutkan dengan pertanyaan dan pernyataan antar peserta didik.

2. Strategi math talk bersinergi dengan kemampuan berpikir kritis dan kemampuan komunikasi melalui komponen- komponen yang terdapat pada masing-masing kategori. Di saat math talk diterapkan, secara bersamaan kemampuan berpikir kritis dan dan komunikasi dikembangkan.

3. Strategi math talk dapat meningkatkan kemampuan berpikir kritis dan kemampuan komunikasi. Keempat komponen math talk bersinergi secara langsung kepada kemampuan berpikir kritis dan kemampuan komunikasi.

\section{Referensi}

What is critical thinking, Joe Lau \& Jonathan Chan, http://philosophy.hku.hk/think/critical/ct.php. Di akses tanggal 28 Desember 2017

Hufferd-Ackles, K., Fuson, K. C., and Sherin, M.G. 2004, Describing Levels and component of a math talk learning community. Journal for research in Mathematics Education, (35 (2), 81-116

Introduction Math Talk, https://www.eduplace.com/math/.../mathtalk/mathtalk_g5., di akses 27 Februari 2018 
Ifada Novikasari, 2009, Pengembangan Kemampuan Berpikir Kritis Siswa Melalui Pembelajaran Open Ended, Jurnal Pemikiran Alternatif Pendidikan, 14 (2) 346364

National Council of Teacher of Mathematics (1991). Professional standards for teaching Mathematics. Retrived from http://www.nctm.org/standards/content.aspx $? \mathrm{id}=26628$

Genia Connel, 2014, Math Talk 101. https://www.scholastic.com/teachers/blog-posts/geniaconnell/math-talk-101/. Di akses Februari 2018 